\title{
Sakai: A Mobile Learning Platform
}

\author{
https://doi.org/10.3991/ijim.v13i11.10800 \\ Corrienna Abdul Talib $\left.{ }^{(}\right)$ \\ Universiti Teknologi Malaysia, Johor, Malaysia \\ corrienna@utm.my \\ Hassan Aliyu \\ Faculty of Education Sokoto State University, Sokoto, Nigeria \\ Adi Maimun Abdul Malik, Kang Hooi Siang \\ Universiti Teknologi Malaysia, Johor, Malaysia \\ Igor Novopashenny \\ University of Bremen (Uni HB), Bremen, Germany \\ Marlina Ali \\ Universiti Teknologi Malaysia, Johor, Malaysia
}

\begin{abstract}
These days, humans have been witnessing related technological and social development, by means of which mobile technologies and Internet yield global access to information with mobility of knowledge. Mobile learning platforms are designed based on electronic learning (e-learning) and mobility. It is regarded as a useful way to enhance the learning process. Sakai as a mobile learning platform, design intentions are to be adaptable to any educational purposes, within or outside the institution, dependent on the provision of effectiveness in classroom instruction based on the learning style of the students, extensible on the cultivation of thinking skills in the learner, and efficient in communicating and exchanging data among its enrolled classroom members and other online platforms. This study employed a systematic review of related literature to investigate the predominant research methodology adopted by various scholars to assess necessary factors concerning mobile learning platform. Fifteen articles are selected based on established criteria. The findings indicated that most of the researchers used quantitative research methodology in investigating the effectiveness and concern variable of mobile learning. Also find out is that most of the outcome of the studies include, achievement, perception, pedagogy, motivation and mobile learning platform as a form of educational technology.
\end{abstract}

Keywords - Sakai, mobile learning, educational technology 


\section{Introduction}

Today, mobile learning technologies exert more effects on classroom instruction, and link formal with informal learning, work and leisure [1]. These appeared to be among the most interesting pigure for teachers because majority these channels used for instruction in the classroom are cheep and provide wide access to the available instructional resources. In a situation by which mobile learning technologies are simultaneously used with wireless internet connectivity, learning activities can be monitored and coordinated between locations. But, the processes of planning, designing and implementing mobile learning technologies into the classroom activities thereby enhancing appropriate support for the learners are both challenging and complex [1]. The effects of these innovative mobile learning technologies on formal instructions in/outside classroom need to be evaluated and appraised. This study, among oter things, intends to develop and promote collective understanding of mobile learning technologies and their new possibilities in the improvement of learning and teaching effectiveness. It will describe clearly how moblile technologies and platform were integrated into educational practices, and assess their impacts to date.

The recent advancements of in mobile learning are changing the primary purpose of mobile devices from receiving and making calls to retrieving the latest information on any subject. 'A society which is mobile, which is full of channels for the distribution of a change occurring anywhere, must see to it that its members are educated to personal initiative and adaptability. Otherwise, they will be overwhelmed by the changes in which they are caught and whose significance or connections they do not perceive' [2].

Nowadays, the effects of technological and social development brought by mobile learning technologies and platforms were serious experienced, through which they provide, with the used of Internet, the global access to information anytime-anywhere, thereby enhancing the mobility of knowledge. In the past twenty years, an educational institution in Malaysia teaching English language had no access to contemporary language sources; now it has the worldwide web [2]. Moreover, in not morethan ten years, a farmer in rural areas of Federal Republic of Kenya had no communication with the nearest city, now he carries a mobile phone. Today, people live daily life in their society by carrying along the mobile technologies with them, which served as a "channels for distribution of change".

\section{Background to the Study}

Currently, many educational institutions across the world banned utilization of mobile phones in the classroom which consequently implies that learners cannot benefit from the relevance smartphones in teaching and learning [3]. This regulation was mainly form based on reasons that learners misuses their moblile devices during classroom instruction. Many students are seen playing video games, media files and chatting with friends while instructions are going on in the classroom. Moreover, those 
students have more social applications than instruction tools that could facilitate learning and enhance skills development.

Conversely, greater than before, the ubiquity and functionality of mobile phones changed mind of several teachers; making them to assessing the instructional benefits of mobile devices; thereby re-evaluating the restrictions/regulations set by the schools on the utilization of mobile technologies in the classroom [4]. Many scholars called mobile phones the "Swiss army knife" of technology for the reason that they have a emergent number of tools (for example, audio/video players \& recorders, digital cameras, Internet access, calculators, apps, e-mail and texting) which are of greater advantage to instruction in the classroom.

Nowadays learning via mobile devices is widely accepted by the learner community [5]. Teachers must allow the use of the mobile device in the classroom because they are beneficial in content creation, student-centred learning, authentic learning and differentiation of instruction, as well as assessment and reflection. Additionally, the portability of cell phones provides teachers and students anywhere/anytime access to course material.

Sakai as a mobile learning platform, design intentions are to be adaptable to any educational purposes, within or outside the institution, dependent on the provision of effectiveness in classroom instruction base on the learning style of the students, extensible in the cultivation of thinking skills in the learner, and efficient in communicating and exchanging data among its enrolled classroom members and other online platforms. Zamfirache et al. (2013), point out that today, mobile learning leads to a better organization of available resources and an 'anywhere, anytime' type of access. The transportability of mobile platforms or devices does not only allows learners to study across contexts, but also provides teachers and educators with the chances for creationg new learning models [7].

\section{$3 \quad$ Mobile Learning and Sakai}

The portability of platforms and devices which uses internet technology enable the mobility of the learner and the learning materials [8] \& [9]. Mobile learning is defined as the development of art of using portable electronic platforms or devices to improve learning experience while on the move [10]. It is also defined as an extension of electronic learning through internet and mobile technology [11].

Mobile learning (m-learning) is designed based on electronic learning (e-learning) and mobility [12]. It is regarded an interesting and efficient means for improving the learning process [13].

Having access and utilization mobile platforms or devices single-handedly does not simply imply mobile learning experience [10]. Sufficient knowledge and awareness of the application of today's technology in educational environment and most importamtly for the purpose of learning is the minimum requirement for learners to effectively adopt mobile learning. There are four basic assumptions of mobile learning theories proposed by [14]. The first assumption attempted to distinguish distinct features of mobile learning compared to other types of learning activity. 
- It states that students today are moving continuously. People learn while moving around the universe experiencing new events ideas and use varying learning resources to gained knowledge and skills in a particular place and apply or develop them in the other area [15]. Students study all the time, through "revisiting knowledge that was gained earlier in a different context", and more broadly, through ideas and strategies gained in early years providing a framework for a lifetime of learning. They move from topic to topic, managing a range of personal learning projects, rather than following a single curriculum. By making learning to become mobile as an object of analysis, means for which knowledge and skills may be better understood to be transferred through contexts such as school and home, ways for which learning could be better managed across life transitions, and a means by which fresh technologies are developed to support a society in which mobile individuals remotely endeavours to cram learning into the interstices of daily life.

- Considerable learning takes place outside classrooms as people instigate and structure their activities to enable educational processes and outcomes.

- However, there is thought that the theory of mobile learning should be seen as all other learning theory and must be based on current issues of practices that enable true learning. To initiate educational effectiveness in all ages and subject areas, a synthetic study was conducted by National Research (1999). It is assumed that effective learning must be:

- Learner-centred: this is builds on the existing knowledge and skills of the learner, empowering them to reason from their own experience;

- Knowledge centred: this is built from a strong grounds of validated knowledge (curriculum), efficiently delivered by teachers on the course of instruction through inventive utilization of concepts and procedures;

- Assessment centred: in this approach, assessment is complemented to the students' ability, offering formative guidance and evaluation that builds on success;

- Community centred: prosperous students form a mutually primitive community, supporting less able students and sharing knowledge.

- Lastly, a theory of mobile learning need to consider the abundant use of cooperative and personal technology. Studies indicated that more than $75 \%$ of the overall population of which over $90 \%$ of youth possess mobile devices [16] \& [14]. These information mask wide differences in accessibility of technology all over the globe, then again indicated a trend towards peoples' possession of at least one or more technological device comprising of music players, portable computers, hanset and cameras.

It is suggested that mobile learning platform must be tested based on the following:

- Enables the students' mobility

- Cater for informal and formal learning

- The approach (both constructive and social process)

- Considers learning as a personal activity found to be mediated by technology [14] 
Because of increased need for utilization of mobile platforms (like Sakai) and devices (like smartphones) by the individuals in the society, recently mobile technologies field significant advances [17]. The products of these advancement are highly sophisticated and portable notebooks, smartphones, Bluetooth and wireless technologies as well as General Packet Radio Service (GPRS) connections to mention but a few. Equally important features of these advancement of mobile platforms an deviced include information transmission, transformation, convertion formating and recording. Today, Sakai (as mobile platform for learning) provided instruction that is executable and flexible in an of the mentioned technology. The following are the conclusion made by many studies with regards to the mobile learning flexibility while using platform like Sakai:

- In reality, it is the user (the learner) that is mobile, and not the technology (the technology can access learning material anytime-anywhere)

- Learning process is interlinked with related activities as integral part of everyday life

- While learning take place goals are satisfied

- The learning management and control can be distributed

- Through interaction, learning context is built by learners

- The process learning through mobile platform can be both conflicted and supported with formal education

- Mobile learning promotions profound ethical issues of ownership and privacy.

The most crucial factor for accomplishment was whether or not the learners perceived that their productivity was greater than before by using mobile learning [18]. Interestingly, many researchers including Azzam et al. indicated that although their respondents using mobile learning for the subject area were legitimately satisfied, they however feel motivated and curious to use mobile learning in the future.

This study is a systematic review of the literature on mobile learning platforms. Many reviews conducted have a different approach to a problem. Few of these articles were research that are unable to indicate educational setting for which investigation was carried out. In the reporting of findings, the authors did not describe the level of education of the learners. For example:

- In 2009, to analyze the context, tools, control, communication, subject and objective of each study, Frohberg, Göth, and Schwabe carried out a study in which they reviewed about 102 projects conducted in the area of mobile learning [19].

- In the year 2013, 74 articles were reviewed to investigating research purposes, methods, and outcomes by Cheung and Slavin. In this study pk-12 were chosen as the respondents. Also studied are the levels of education, subject matter domains, types of mobile devices, context, learning theories and geographic distribution [21].

- In 2014, Liu, Scordino, Geurtz, Navarrete, Ko, and Lim made a systematic review of articles related to mobile learning from 2007-2014 on k-12 students to investigate methods, research purposes, outcomes and academic areas [20]. 
- Some researchers have specifically identified multiple educational settings in their reviews.

- In the year 2011, Hwang and Tsai studied adult learner, higher education and K-12 by reviewing articles from 2001 to 2010 on the area of mobile learning. In this study, the countries, grade level and subject areas reported where it took place were reported [22].

- Wu, Wu, Chen, Kao, Lin and Huang carried out a systematic review in 2013 to study mobile learning on K-12 students [23].

\section{Objectives}

The study intended to

- Find out the predominant research methodology used by the researcher to evaluate the effectiveness of mobile learning platforms.

- To compare the results of the related study with the feature Sakai as a new-aged mobile learning platform

\section{$5 \quad$ Methodology}

This study is a systematic review of mobile learning platform that was published between 2005 and 2018. It considered studies conducted in learning institutions (both secondary and tertiary) and used English as the language for which the article was written. Seven databases had been carefully searched including Springer, Science and Education (ELSEVIER), ERIC, SCOPUS, Web of Science, Google Scholar and Journal of Computer Assisted Learning. The searching was executed using terms including online learning, mobile learning, e-leaning, m-learning, wireless learning, situated learning, location aware, digital learning, context aware and ubiquitous learning from electronic, manuals and journals. The terms used in searching articles were the commonly used words in defining mobile learning.

The search engine produced over 5,877 articles. Title and abstract were the first formats used in screening an article for qualification for the study. The search was limited to the years 2005 to 2018 , as computer devices became available to the general public in the early 2000s and fresh category of computer era was defined which delivered teachers with a mobile device (such as personal computers and mobile phones). The initial search resulted in 978 articles.

All review articles were eliminated so that the qualified list contains only articles that represented researchers finding in a real field of study. By using a text analysis procedure, the full text of 126 articles was read to make sure that the questions stated in each work was being answered and were therefore relevant to the current review. Based on the research questions, seven elements were selected for analysis:

- Research design,

- Methodology, 
- Outcomes of learning,

- Subject matter (mobile learning)

- Levels of educational, (Secondary and tertiary institutions)

- Context of educational (formal, non-formal, and informal),

- Type of respondents (students and teachers)

Articles that do not meet those seven elements stated were extracted living 53 research papers. However, articles that have to attain their own objectives were also eliminated. Finally, fifteen articles are selected and reviewed. These articles are summarized in Table 1.0

Table 1. Summary of Articles

\begin{tabular}{|c|c|c|c|c|c|c|}
\hline & Author & Respondents & Context & Method & Design & Findings \\
\hline 1 & $\begin{array}{l}\text { Ismail, } \\
\text { Azizan and } \\
\text { Gunasegaran } \\
(2016)\end{array}$ & 551 students & Formal & Quantitative & Survey design & $\begin{array}{l}\text { The students are moderately ready } \\
\text { for use of mobile learning. Students } \\
\text { become more curios to continuously } \\
\text { learn with mobile platforms } \\
\text { learning }\end{array}$ \\
\hline 2 & $\begin{array}{l}\text { Motiwalla } \\
(2007)\end{array}$ & 63 students & Formal & $\begin{array}{l}\text { Mixed } \\
\text { method }\end{array}$ & $\begin{array}{l}\text { Survey \& } \\
\text { Interview }\end{array}$ & $\begin{array}{l}\text { The platform provides a better } \\
\text { understanding of the content area. } \\
\text { The students found the platform } \\
\text { useful in addressing their own } \\
\text { problems. An upright } \\
\text { complementary tool for interaction } \\
\text { in the classroom. And lastly, the } \\
\text { students found the interaction tools } \\
\text { easy for discussing course materials } \\
\text { with other students and instructors. }\end{array}$ \\
\hline 3 & $\begin{array}{l}\text { Park, Lee and } \\
\text { Kim (2016) }\end{array}$ & 557 students & Formal & Quantitative & Survey design & $\begin{array}{l}\text { Over } 59 \% \text { of the respondents have } \\
\text { good acceptance of mobile learning } \\
\text { platform for their learning process. }\end{array}$ \\
\hline 4 & $\begin{array}{l}\text { Ciolacu and } \\
\text { Beer }(2016)\end{array}$ & 69 students & Formal & Quantitative & Survey design & $\begin{array}{l}\text { Over } 80 \% \text { of the respondents are } \\
\text { found interested in taking their } \\
\text { subjects in a similar approach and } \\
\text { over } 94 \% \text { of the students gained } \\
\text { knowledge of related subjects }\end{array}$ \\
\hline 5 & $\begin{array}{l}\text { Mahesh, } \\
\text { Jayahari and } \\
\text { Bijlani, } \\
(2016)\end{array}$ & 55 students & Formal & Quantitative & Survey design & $\begin{array}{l}\text { By using a phone students have } \\
\text { grace of utilizing alternative } \\
\text { platform and personal computer by } \\
\text { the time they happened to be in their } \\
\text { classroom and also the attendance } \\
\text { was made for them by the system. } \\
\text { The learners tend to enjoy the } \\
\text { ability of the platform to serves as a } \\
\text { device for diplaying information } \\
\text { and also as a storage. That is the } \\
\text { learning material could be } \\
\text { transferred with the help of internet } \\
\text { or Wifi network to their mobile } \\
\text { phone in which it will be read. } \\
\end{array}$ \\
\hline 6 & $\begin{array}{l}\text { Fatimah \& } \\
\text { Ahmad, } \\
(2016)\end{array}$ & 150 students & Formal & Quantitative & Survey design & $\begin{array}{l}\text { Mobile learning platform improves } \\
\text { students learning effectiveness. } \\
\text { Students The resulting analysis } \\
\text { explained that storage size of }\end{array}$ \\
\hline
\end{tabular}




\begin{tabular}{|c|c|c|c|c|c|c|}
\hline & Author & Respondents & Context & Method & Design & Findings \\
\hline & & & & & & $\begin{array}{l}\text { mobile platform, the memory } \\
\text { limitation and life span of mobile } \\
\text { device battery formed the major } \\
\text { barriers facilitating mobility in the } \\
\text { process of learning. Finally, the role } \\
\text { played by computing in supporting } \\
\text { mobile learning was in agreement } \\
\text { with majority of the respondents of } \\
\text { the study. }\end{array}$ \\
\hline 7 & $\begin{array}{l}\text { Shamir-Inbal } \\
\text { and Blau, } \\
(2016)\end{array}$ & $\begin{array}{l}5 \text { teachers } \\
\text { and students }\end{array}$ & Formal & Qualitative & & $\begin{array}{l}\text { The finding indicated that naturally, } \\
\text { learners come across recent } \\
\text { technologies and learn about } \\
\text { them-through exchanging } \\
\text { information and exploration } \\
\text { repetitively. The teachers are more } \\
\text { successful in developing their pro- } \\
\text { fessional digital wisdom as teachers } \\
\text { than in exploring new technologies } \\
\text { as learners }\end{array}$ \\
\hline 8 & $\begin{array}{l}\text { Kusumastuti } \\
\text { et al., (2016) }\end{array}$ & 120 students & Formal & Quantitative & Survey design & $\begin{array}{l}\text { The results showed that students } \\
\text { have the motivation to learn and use } \\
\text { a mobile device with high category } \\
(67.06 \%) \text {. Over } 80 \% \text { watch } \\
\text { instructional videos. }\end{array}$ \\
\hline 9 & $\begin{array}{l}\text { Dinh et al., } \\
(2013)\end{array}$ & & Formal & Quantitative & Survey design & $\begin{array}{l}\text { The findings indicated that mobile } \\
\text { learning platform is sufficient in } \\
\text { providing optimal services for } \\
\text { mobile learners }\end{array}$ \\
\hline 10 & $\begin{array}{l}\text { Thomas, } \\
\text { O'Bannon } \\
\text { and Bolton, } \\
(2013)\end{array}$ & 79 teachers & Formal & Quantitative & Survey design & $\begin{array}{l}\text { Instructors acknowledged learners' } \\
\text { motivation and engagement as the } \\
\text { principal benefit }\end{array}$ \\
\hline 11 & $\begin{array}{l}\text { Sung, Hwang } \\
\text { and Liu, } \\
(2013)\end{array}$ & 51 students & Formal & Quantitative & Experimental & $\begin{array}{l}\text { Mobile learning not only promoted } \\
\text { the students' self-efficacy but also } \\
\text { improved their learning } \\
\text { achievements. }\end{array}$ \\
\hline 12 & $\begin{array}{l}\text { Wu, Hwang } \\
\text { and Tsai, } \\
(2013)\end{array}$ & 58 students & Formal & Quantitative & Experimental & $\begin{array}{l}\text { The learning achievements of } \\
\text { learners was obervered to have been } \\
\text { improved significantly with respect } \\
\text { to several cognitive processes in } \\
\text { Bloom's taxonomy of educational } \\
\text { objectives, such as "analyzing" and } \\
\text { "evaluating." Consequently. }\end{array}$ \\
\hline 13 & $\begin{array}{l}\text { Lan and } \\
\text { Huang, } \\
(2012)\end{array}$ & 32 students & Formal & $\begin{array}{l}\text { Mixed } \\
\text { method }\end{array}$ & \begin{tabular}{|l|} 
Survey \& \\
Experimental
\end{tabular} & $\begin{array}{l}\text { Satisfactory and encouraging in } \\
\text { terms of the effectiveness of the } \\
\text { supported mobile learning } \\
\text { environment. also found a positive } \\
\text { improvement in reflection levels } \\
\text { toward traffic violations among } \\
\text { groups following the experiment }\end{array}$ \\
\hline 14 & $\begin{array}{l}\text { del Carmen } \\
\text { Valderrama } \\
\text { Bahamóndez, } \\
\text { Häkkilä and } \\
\text { Schmidt, } \\
(2012) \\
\end{array}$ & $\begin{array}{l}78 \text { students } \\
\text { and } 6 \\
\text { teachers }\end{array}$ & Formal & Quantitative & Survey design & $\begin{array}{l}\text { The results show that there is } \\
\text { potential for a tighter integration of } \\
\text { applications to improve the learning } \\
\text { experience }\end{array}$ \\
\hline
\end{tabular}




\begin{tabular}{|c|c|c|c|c|c|c|}
\hline & Author & Responden & Context & Method & Design & Findings \\
\hline 15 & $\begin{array}{l}\text { Parsazadeh et } \\
\text { al., (2018) }\end{array}$ & 14 teachers & Formal & Qualitative & & $\begin{array}{l}\text { Over } 88 \% \text { of experts have } \\
\text { consented on all usability items } \\
\text { represented in the usability } \\
\text { questionnaire. The usability } \\
\text { evaluation survey for mobile } \\
\text { learning applications can help to } \\
\text { improve user satisfaction and } \\
\text { reductions in training costs. The } \\
\text { decrease in costs attracts many } \\
\text { researchers, interface designers and } \\
\text { project managers to employ the } \\
\text { usability evaluation when designing } \\
\text { the interfaces for mobile } \\
\text { learning applications. }\end{array}$ \\
\hline
\end{tabular}

\section{Findings of the Study}

The review conducted intended to address the objectives of the study which include to (i) find out the predominant research methodology used by the researcher to evaluate the effectiveness of mobile learning platforms and (ii) compare results of the related study with the feature Sakai as a new-aged mobile learning platform. These are addressed in the subsection below.

\subsection{The predominant methodology of studies used by researchers}

As indicated in Table 1.0 two articles employed the mixed method. An extension of e-learning into wireless/ handheld $(\mathrm{W} / \mathrm{H})$ computing devices was investigated with the help of a mobile learning (m-learning) framework [24]. Mixed method was adapted to a population of 63 students of the tertiary institution. It is indicated by the results of the study that the mobile learning platform provides a improved understanding of the content area. The students involved in the study found the platform useful in addressing their own problems. Students perceived that the mobile learning platform is a good complementary tool for interaction inside classroom. And lastly, the students found the tools for interaction easy for discussing materials for learning with instructors, expert and other students.

Moreover, [5] studied integrated mobile communication technologies and a global positioning system (GPS) to construct an instant, convenient report of the mobile network service system, to improve learners' traffic violation reflection level. In this study, a mixed method is adapted to a population comprising of 32 students. The findings of the study indicated that the respondents expressed their rating as suitable and inspiring in terms of the efficiency of the support delivered on the mobile learning environment. The study also found a positive improvement in reflection levels toward traffic violations among groups following the experiment.

However, two articles also adopted a qualitative study in the research. [25] Investigated a pilot of integrating mobile learning using tablet computers in the formal education. The study qualitatively uses five teachers and students through which it draws 
a conclusion based on its findings that students learn about new technologies naturally - through repetitive explorations and by exchanging information. The teachers are more successful in developing their professional digital wisdom as teachers than in exploring new technologies as learners. [26] also investigated the usability of mobile learning applications in which 14 teachers were interviewed. The findins demonstrated that higher than $88 \%$ of specialists agreed on all test items represented in the usability questionnaire. The mobile learning applications usability evaluation survey can aid to mend user satisfaction and reductions in training costs. The drop in costs becomes appealing to various scholars, designers of system interface and managers of project to adopt the usability evaluation when designing the interfaces for mobile learning applications.

It is clear that the quantitative method was the predominantly used in the investigation of effectiveness and other factors involving mobile learning in both secondary schools and the tertiary institutions. Over 11 researchers [27][28][12][29][13][7][10][3][4][9]\&[30] adapted qualitative study with survey research design. Thus, this indicates that quantitative methodology is predominantly used in the investigation of mobile learning effectiveness and other factors.

\subsection{Comparison of results of reviewed studies with Sakai features}

The results of the reviewed articles are summarized as the achievement of the respondent in using mobile learning platform, the perception of the respondents with regards to mobile learning, pedagogical approaches of mobile learning platforms and educational technology tool. These are discussed in the following subsection.

Achievement: Studies investigated students' achievement in using mobile learning platform in different ways including

- The effects of using mobile learning

- Learning performance on certain skills

- Sharing and communication of ideas

- Educational objectives attainment. [30]

Reported that when mobile learning is effectively integrated, the learners' achievements in learning will significantly improve with respect to several cognitive processes in Bloom's taxonomy of educational objectives, such as "analyzing" and "evaluating." [28], also reported that there is potential for a fitted mobile applications integration to enhance students' experience in learning. Thus, mobile learning is significantly valuable in developing students' achievements through the improved learning experience. However, [7] concluded that mobile learning not only promoted the students' self-efficacy but also improved their learning achievements.

Sakai in the same vein is a platform that enables teachers to convey instructional materials to their students in an eloquent way that triggered learner development within a very limited time. It administers an effective assessment to monitor students' advancement or their progress in learning of both the content and skills. Thus, teachers 
that are dared in developing their student's achievement should make use of Sakai to enable them attained their objective with negligible barriers.

Perception: Students' perceptions of mobile learning are also investigated in different ways including

- Students' general perception

- Perception of using the mobile platform and computer or Android device

- Perception based on gender

- Perception based on ease nature of mobile learning platform

The learners' perceptions concerning utilization of mobile learning are very crucial, because individuals' perceptions impact on the way they behave [16]. If learners perceive that mobile learning has little or no value, then they could be less probable to embrace the use of mobile learning. It is imperative to state that perceptions can be entrenched in traditional practices and biased to those traditional ways. Many studies [27][10][9]\&[26] describe both teachers and students' perception on mobile learning.

However, [26] indicated that higher than $88 \%$ of specialists have consented on all test items represented in the usability questionnaire. Similarly, [10], reported that students indicated they're interested to know more about mobile platforms learning and to use them in all subject areas. In addition, [9] also reported that over 59\% of the respondents have good acceptance of mobile learning platform for their learning process. [27] used mobile learning platform with an adaptive course user interface to teach students mathematics in which about $80 \%$ of the respondents are interested in taking their subject in a similar approach. Moreover, over $94 \%$ of the students gained knowledge of the related subject through the mobile learning platform instruction as a supplement to the content area learned.

Pedagogy: Pedagogy is considered as the approach which the platform adopted or integrated to realize the educational goal [31]. Sakai is a mobile platform with the aim of enhancing learners' achievement. It scope encompasses:

- Ways in which podcasts could be utilized to support learning in-or-out of the classroom

- Means by which barcodes could be used in a printed text

- Manner for which mobile devices could scaffold learning. [25] indicated that the teachers more successful in developing their professional digital wisdom as teachers than in exploring new technologies as learners.

Empirical evidence indicates that M-learning can support students in learning across many subjects, including education [32], science [33], business [34] and information technology [35].

Technologies are always seemed by most education providers as catalysts which can revamp the process of teaching and learning. With the aid of technology, instructors will be able to conduct teaching to the extent that is- yond the traditional classroom setting [10]. Mobile learning emerged in response to the need for ubiquitous and 'on-the-go' access to learning which completes the missing puzzle in classroom instruction. With the use of mobile devices such as mobile phone, smartphone, and Per- 
sonal Digital Assistants (PDA), mobile learning is gaining popularity in its ability to facilitate teaching and learning activities, such as monitoring students' progress and delivering learning contents in an interactive interface. The fact is, these technological devices have become a must-have gadget due to its mobility features. The abundance of these mobile technologies has also added value into the educational atmosphere thereby opens the door for the practitioner, educators and education policymakers to consider the implications of these devices for modern teaching and learning environment.

Experience of learners in learning and communication are improved with the helps of mobile learning. Distance learners were provided better access learning resources. It also gives positive impacts on students' motivation, collaboration, information sharing, mobility and interactivity.

Among the human factors that need to be urgently addressed before a successful implementation of mobile learning is the learners' readiness in embracing the technology for their learning. Several studies have reported their findings on respondents' readiness for mobile learning in terms of their ownership of mobile devices.

Mobile learning as educational Technology: Utilization of advanced technology is nearly indispensable as an addition to the regular classroom instruction. The unique trait of these today's students does not only shaped the personalities but also contributes towards their learning preferences that has created a need for new tools and supplemental learning environments such as multiple media and simulation-based environments [36], interactive learning environments, less lecture, active learning approaches, multimedia-enriched environment, collaborating with peers [3] are some of the pedagogical approaches to reach the digital generation. Educational technology has significant implication in promoting learning, improves the quality of education by facilitating self-learning, collaborative learning, problem solving aptitude, critical thinking, ability to communicate and space for real-time conversation, at the same time making the traditional method more meaningful and affective [37].

Computer technology has proliferated tremendously in the last few decades with the use of Internet, email, multimedia technology, and intelligent tutoring system on campus [24]. The academic instruction in online learning environment alters the traditional time/space configuration by providing access to learning resources from anywhere at any time, information and content delivery is altered by presenting the materials in different media, parallel access paths, and assessments via computer logs and software packages. Similarly, communication and interaction process between the learner and teacher is altered with the novel usage of synchronous and asynchronous communication tools that allow sharing of ideas, virtual collaboration and better archival capabilities for reflecting on previous interactions. Finally, ICT alters the roles of students and instructors. Students are empowered with the learning responsibility with their individual learning goals, schedules and assessments, while the instructor's role shifts from "a sage on the stage" to "a guide on a side" [38]. One of the goals of this project was to explore whether these pedagogical shifts impact them-learning environment as well.

By means of mobile learning, learners switch from passive learning to active, intellectual [9] and engagement emotionally in their learning tasks [39]. Mobile learning 
impacts positively on the learning outcomes as well as students' attitudes and educational processes [40].

\section{Conclusion}

A systematic review of mobile learning literature published between 2005 and 2018. From a total of 15 selected articles analysing predominant research methodologies thereby comparing findings with the newly developed mobile learning platform called Sakai. The study indicated obvious information that describes the most predominant research methodology used by the researchers investigating mobile learning in formal and informal educational environment. The majority of the researchers (11 out of 15) used a quantitative research method in studying necessary factors in mobile learning. However, the study indicated that most of the findings include the population's perception of mobile learning, pedagogy used, achievement and being a form of educational technology.

\section{Acknowledgement}

The research was supported by European Union program ERASMUS +, Capacity building in higher education, No 73751-EPPI-2016-DE-EPPKA2-CBHE-JP, Innovative teaching and learning strategies in open modelling and simulation environment for student-centred engineering education (InMotion) and Universiti Teknologi Malaysia (Vol 4C118). Any conclusions, options and findings or even recommendations established in this publication are those of the authors and do not necessarily reflect the views of the above-mentioned organizations.

\section{Reference}

[1] A. Kukulska-Hulme, "Introduction. In Mobile Learning," Routledge, pp. 17-22, 2007.

[2] J. Dewey, "Education and democracy," 1916.

[3] G. Mahesh, K. R. Jayahari, and K. Bijlani, "A smart phone integrated smart classroom," Int. Conf. Next Gener. Mob. Appl. Serv. Technol., pp. 88-93, 2016.

[4] K. M. Thomas, B. W. O'Bannon, and N. Bolton, "Cell Phones in the Classroom: Teachers' Perspectives of Inclusion, Benefits, and Barriers," Comput. Sch., vol. 30, no. 4, pp. 295308, 2013. https://doi.org/10.1080/07380569.2013.844637

[5] Y.-F. Lan and S.-M. Huang, "Using Mobile Learning to Improve the Reflection : A Case Study of Traffic Violation,” Educ. Technol. Soc., vol. 15, no. 2, pp. 179-193, 2012.

[6] V. Zamfirache, A. Eftcnoiu, P. Iosif, A.-C. Olteanu, and N. Tapus, "Extending the moodle course management system for mobile devices," Syst. Comput. Sci. (ICSCS), 2013 2nd Int. Conf., pp. 103-108, 2013. https://doi.org/10.1109/icconscs.2013.6632031

[7] H.-Y. Sung, G.-J. Hwang, and S.-Y. Liu, "A Prompt - Based Annotation Approach to Conducting Mobile Learning Activities for Architecture Design Courses,” IEEE 2013 Second IIAI Int. Conf. Adv. Appl. Informatics, no. 0, pp. 1-9, 2013. $\underline{\text { https://doi.org/10.1109/iiai-aai.2013.86 }}$ 
[8] M. El-Hussein, M. Osman, and J. C. Cronje, "Defining mobile learning in the higher education landscape,” J. Educ. Technol. Soc., vol. 13, no. 3, pp. 201-211, 2010.

[9] S. Y. Park, H. D. Lee, and S. Y. Kim, "South Korean university students' mobile learning acceptance and experience based on the perceived attributes, system quality and resistance," Innov. Educ. Teach. Int., vol. 3297, no. December, pp. 1-9, 2016. https://doi.o rg/10.1080/14703297.2016.1261041

[10] I. Ismail, S. N. Azizan, and T. Gunasegaran, "Mobile Learning in Malaysian Universities: Are Students Ready?,” Int. J. Interact. Mob. Technol., vol. 10, no. 3, p. 17, 2016. https://do i.org/10.3991/ijim.v10i3.5316

[11] a. Moura and Others, "Mobile learning: teaching and learning with mobile phones and Podcasts," Eighth IEEE Int. Conf. Adv. Learn. Technol., pp. 631-633, 2008. https://doi.or g/10.1109/icalt.2008.294

[12] H. T. Dinh, C. Lee, D. Niyato, and P. Wang, "A survey of mobile cloud computing: architecture, applications, and approaches," Publ. online inWiley Online Libr., pp. 421-430, 2013.

[13] W. Fatimah and W. Ahmad, "Cloud Computing Role to Address Mobile Learning Barriers : An Exploratory Study of HEIs in Malaysia Cloud Computing Role to Address Mobile Learning Barriers : An Exploratory Study of HEIs in Malaysia," no. November, pp. 553558, 2016. https://doi.org/10.1109/iccoins.2016.7783275

[14] M. Sharples, J. Taylor, G. Vavoula, M. Sharples, J. Taylor, and G. Vavoula, "A Theory of Learning for the Mobile Age To cite this version: HAL Id: hal-00190276 A Theory of Learning for the Mobile Age (pre-print,"pp. 221-247, 2007. https://doi.org/10.4135/9781 473955011.n4

[15] M. Sharples, J. Taylor, and G. Vavoula, "Towards a Theory of Mobile Learning," Proc. mLearn, vol. 1, no. 1, pp. 1-9, 2005.

[16] H. Crompton and D. Burke, "The use of mobile learning in higher education: A systematic review,” Comput. Educ., vol. 123, pp. 53-64, 2018. https://doi.org/10.1016/j.compedu.20 $\underline{18.04 .007}$

[17] F. Ozdamli and N. Cavus, "Basic elements and characteristics of mobile learning," Procedia - Soc. Behav. Sci., vol. 28, pp. 937-942, 2011. https://doi.org/10.1016/j.sbspro.2011.1 $\underline{1.173}$

[18] N. A. Azzam et al., "Performance of American Society for Gastrointestinal Endoscopy guidelines for dyspepsia in Saudi population: Prospective observational study.," World J. Gastroenterol. WJG, vol. 21, no. 2, p. 637., 2015. https://doi.org/10.3748/wjg.v21.i2.637

[19] D. Frohberg, C. Göth, and G. Schwabe, "Mobile Learning projects - a critical analysis of the state of the art: Original article," J. Comput. Assist. Learn., vol. 25, no. 4, pp. 307-331, 2009. https://doi.org/10.1111/j.1365-2729.2009.00315.x

[20] M. Liu, R. Scordino, R. Geurtz, C. Navarrete, Y. Ko, and M. Lim, "A look at research on mobile learning in K-12 education from 2007 to the present," J. Res. Technol. Educ., vol. 46, no. 4, pp. 325-372, 2014. https://doi.org/10.1080/15391523.2014.925681

[21] A. C. K. Cheung and R. E. Slavin, "The effectiveness of educational technology applications for enhancing mathematics achievement in K-12 classrooms: A meta-analysis," Educ. Res. Rev., vol. 9, pp. 88-113, 2013. https://doi.org/10.1016/j.edurev.2013.01.001

[22] G. J. Hwang and C. C. Tsai, "Research trends in mobile and ubiquitous learning: A review of publications in selected journals from 2001 to 2010," Br. J. Educ. Technol., vol. 42, no. 4, pp. 65-70, 2011. https://doi.org/10.1111/j.1467-8535.2011.01183.x

[23] W. H. Wu, Y. C. J. Wu, C. Y. Chen, H. Y. Kao, C. H. Lin, and S. H. Huang, "Review of trends from mobile learning studies: A meta-analysis.," Comput. Educ., vol. 2, no. 59, pp. 817-827, 2012. 
[24] L. F. Motiwalla, "Mobile learning: A framework and evaluation," Comput. Educ., vol. 49, no. 3, pp. 581-596, 2007.

[25] T. Shamir-Inbal and I. Blau, "Developing Digital Wisdom by Students and Teachers: The Impact of Integrating Tablet Computers on Learning and Pedagogy in an Elementary School,” J. Educ. Comput. Res., vol. 54, no. 7, pp. 967-996, 2016. https://doi.org/10.1177/ $\underline{0735633116649375}$

[26] N. Parsazadeh, R. Ali, M. Rezaei, and S. Zolfaghar, "Studies in Educational Evaluation The construction and validation of a usability evaluation survey for mobile learning environments,” Stud. Educ. Eval., vol. 58, no. June, pp. 97-111, 2018. https://doi.org/10.1016/ j.stueduc.2018.06.002

[27] M. Ciolacu and R. Beer, "Adaptive user interface for higher education based on web technology,” 2016 IEEE 22nd Int. Symp. Des. Technol. Electron. Packag., pp. 300-303, 2016. https://doi.org/10.1109/siitme.2016.7777299

[28] E. del Carmen Valderrama Bahamóndez, J. Häkkilä, and A. Schmidt, "Towards better UIs for mobile learning," Proc. 11th Int. Conf. Mob. Ubiquitous Multimed. - MUM '12, p. 1, 2012. https://doi.org/10.1145/2406367.2406415

[29] D. L. Kusumastuti, V. U. Tjhin, K. Soraya, and I. I. Service, "Use of Mobile Devices to Improve Student Learning Motivation on distance learning," vol. 2014, pp. 1-5, 2016. https://doi.org/10.1145/3176653.3176729

[30] P.-H. Wu, G.-J. Hwang, and W.-H. Tsai, "An Expert System-based Context-Aware Ubiquitous Learning Approach forlrConducting Science Learning Activities," Educ. Technol. Soc., vol. 16, no. 4, pp. 217-230, 2013.

[31] C. L. Scott, "The Futures Of Learning 3: What Kind Of Pedagogies For The 21st Century?," Work. Pap. Prep. Learn. 21st Century Competencies Ski. Overall Vis. Twenty-First Century Pedagog. Conclusions, Next Steps Futur. ISSUES, pp. 1-21, 2015.

[32] Y. Liu, H. Li, and C. Carlsson, "Factors driving the adoption of m-learning: An empirical study.," Comput. Educ., vol. 55, no. 3, pp. 1211-1219, 2010. https://doi.org/10.1016/j.co mpedu.2010.05.018

[33] C. A. Talib, M. Ali, R. Zawadzki, N. S. Baharuddin, N. K. Thoe, and H. Aliyu, "VideoBased Learning In Chemistry Education : Exemplars, Issues And Challenges," SEAMEO RECSAM, no. 12, pp. 35-51, 2017.

[34] K. Mac Callum and L. Jeffrey, "The Influence of Students' ICT Skill and their Adoption of Mobile Learning,” Australas. J. Educ. Technol., vol. 29, no. 3, pp. 303-314, 2013.

[35] H. Hamidi and A. Chavoshi, "Analysis of the essential factors for the adoption of mobile learning in higher education: A case study of students of the University of Technology.," Telemat. Informatics, vol. 4, no. 35, p. 1053-1070, 2018. https://doi.org/10.1016/j.tele.201 7.09.016

[36] M. Al-Emran, V. Mezhuyev, and A. Kamaludin, "Technology Acceptance Model in Mlearning context: A systematic review," Comput. Educ., 2018. https://doi.org/10.1016/j.co mpedu.2018.06.008

[37] J. Traxler, "Defining, Discussing and Evaluating Mobile Learning: The moving finger writes and having writ” Int. Rev. Res. Open Distance Learn., vol. 8, no. 2, 2007. https://doi .org/10.19173/irrodl.v8i2.346

[38] R. Nachmias and A. Gilad, "Needle in a hyperstack: Searching for informatrion on the world wide web," J. Res. Technol. Educ., vol. 34, no. 4, pp. 475-486, 2002. https://doi.org/ $\underline{10.1080 / 15391523.2002 .10782362}$

[39] M. Wang, R. Shen, D. Novak, and X. Pan, "The impact of mobile learning on students' learning behaviours and performance: Report from a large blended classroom," Br. J. 
Educ. Technol., vol. 40, no. 4, pp. 673-695, 2009. https://doi.org/10.1111/j.1467-8535.200 8.00846.x

[40] A. I. M. Elfeky and T. S. Yakoub Masadeh, "The Effect of Mobile Learning on Students' Achievement and Conversational Skills,” Int. J. High. Educ., vol. 5, no. 3, pp. 20-31, 2016. https://doi.org/10.5430/ijhe.v5n3p20

\section{Authors}

Corrienna Abdul Talib is a senior lecturer at the Faculty of Social Sciences and Humanities, Universiti Teknologi Malaysia (UTM).

Hassan Aliyu is an assistant lecturer at the Faculty of Education, Sokoto State University, Nigeria. aliyu.hassan@ssu.edu.ng

Adi Maimun Abdul Malik is a professor at the Faculty of Engineering, Universiti Teknologi Malaysia. adi@fkm.utm.my

Kang Hooi Siang is a senior lecturer at the Faculty of Engineering, Universiti Teknologi Malaysia. kanghs@utm.my

Igor Novopashenny is a professor at the University of Bremen (Uni HB), Bremen, Germany. Igor@escience.uni-bremen.de

Marlina Ali is a lecturer at the Faculty of Social Sciences and Humanities of Universiti Teknologi Malaysia (UTM). p-marlina@utm.my

Article submitted 2019-05-05. Resubmitted 2019-06-19. Final acceptance 2019-07-10. Final version published as submitted by the authors. 